\title{
KÜRESEL ÇATIŞMANIN YENI ALANLARI: KAYNAK SAVAŞLARI
}

Klare, Michael T. (Çev. Özge İnciler) (2001). The New Landscape of Global Conflict: Resource Wars, İstanbul: Devin Yayinclik, 336 sayfa.

Firat KAYA

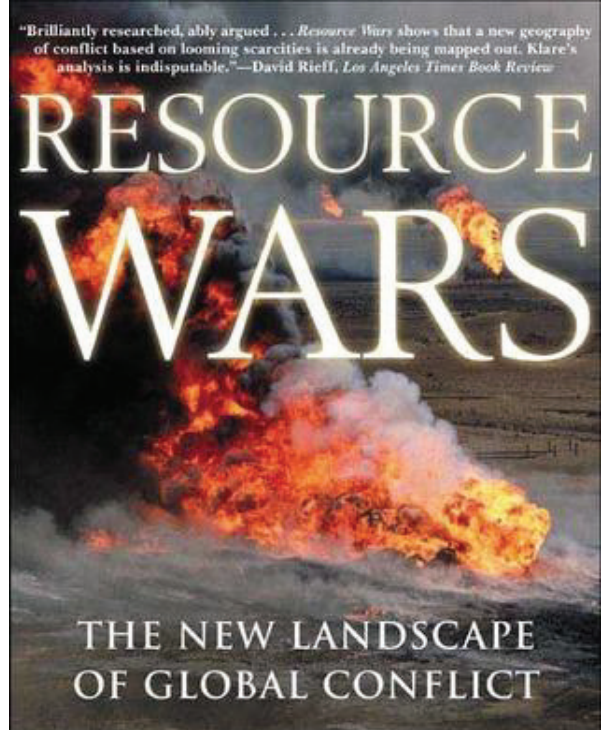

Michael T. Klare

AUTHOR OF ROGUE STATES AND NUCLEAR OUTLAWS
Küresel çatışmalar tarihte olduğu gibi halen sürüp gitmektedir. Daha eski tarihlerde çatışmalar ideolojik, sosyal, siyasal vb. bir takım etkenler ile yaşanmaktayd 1 ancak artık küresel boyutlu savaşlar değerli kaynaklar ve ihsan ettikleri güç ve zenginlik üzerine yoğunlaşmıştır. Yazar Michael T. Klare tarafindan kaleme alınan kitap, küresel çatışmaların arka planını oluşturan başlica nedenleri ve küresel çatışmaların yeni görünümünü inceleyen bir çalışmadır.

Sanayi devrimi ve peşinden gelişen küreselleşme hareketleri, ekonomik büyüme düşüncesini ve buna paralel olarak hammadde ve kaynak ihtiyacını doğurmuştur. Artan refah düzeyleri ile birlikte nüfus hızla artmıştır. Bu temeller üzerinde değerli kaynaklara olan ihtiyaç başta büyük ülkeler olmak üzere birçok ülkenin dikkatini üzerine çekmiş ve kaynaklara hâkim olma düşüncesi çekişmeleri beraberinde getirmiştir. Bu nedenlerle ard1 arkası kesilmeyen kaynak savaşları ve çatışmaları yaşanmıştır. Bütün bu olaylar kitabın temel hareket ettiği alanı oluşturmaktadır. Konuya ilişkin çalışmalar oluşturan, başta akademisyenler, yazarlar ve bürokratlar için ilgi

1 Yüksek Lisans Ögrencisi, Giresun Üniversitesi, Sosyal Bilimler Enstitüsü, Siyaset Bilimi ve Kamu Yönetimi A.B.D, e-posta: frtkya52@gmail.com 
uyandıran kitap; konuya ilgi duyacak geniş bir okuyucu kitlesine hitap edecek niteliktedir.

Kullanılan sade dili ve akıcılık sağlayan anlatımı ile kitap; oldukça geniş kaynakçasıyla göz doldurmaktadır. Bir diğer yönü ile kitap, dünyada artan savaş eğilimlerinin ve çatışmaların gerçekte göz ardı edilen asıl sebebine mercek tutarak okuyucularına önemli bilgiler temin etmektedir. Ayrıca insanları küresel çatışmalar üzerinde aydınlatarak ve sunduğu önerilere dikkat çekerek alanında tartışmaların yoğunlaşmasına zemin hazırlayacak nitelikte olduğu belirtilmelidir.

Kitabın içeriğine yönelik yapılacak olumsuz eleştirilerden biri, konuların birbiriyle çok bağlantılı olmasından dolayı kaynaklanan tekrarlardır. Diğer bir olumsuz eleştiri ise, istatiksel rakamlarla ve verilerle çok fazla ayrıntılı bilgiler vermesidir. Ayrıca daha çok popülerliği olan petrol, doğalgaz gibi değerli kaynakların kontrolü ve egemenliği için yapılan çekişmelere ve çatışmalara daha fazla yer verirken, su, maden, kereste gibi diğer değerli kaynakların tahsisi ve üzerinde egemen olmak için verilen mücadele ve çatışmalara daha az yer vermesi eleştirilmesi gereken diğer bir konudur.

Bu bağlamda kitaba kısaca göz atılacak olursa, 'Zenginlik, Kaynaklar ve Güç: Küresel Güvenliğin Değişen Parametreleri' başlıklı birinci bölümde, Amerika, Rusya, Çin ve Japonya gibi büyük devlerin güvenlik politikalarının, değerli kaynakların tahsisi ve kontrolünü elinde tutma gereksinimlerinin şekillendirdiği anlatılmaktadır. Dünya'nın artan nüfusu, ekonomik büyüme rekabeti gibi nedenlerle enerjiye yönelik bağımlılığın artmasına, buna karşılık kaynakların görece kıt olarak varsayılmasına ve giderek daha fazla tükenmesine dikkat çekilmiştir. Bu durumun başta büyük devletler olmak üzere birçok devletin kaynaklar için rekabetini artırmasında ve politikalarının şekillenmesinde önemli rol oynadı̆̆ının vurgusu yapilmaktadir.

Kitabın, 'Petrol, Coğrafya ve Savaş: Petrol Bolluğunu Elde Etme Rekabeti' başlıklı ikinci bölümünde, küresel enerji talebinde, ekonomi, teknoloji gibi birçok alanda hızlı büyüme, sosyal alanda insanların refah düzeylerinin artması ve tüketici toplumuna hızla geçiş beraberinde petrole olan talebin artmasına neden olduğuna vurgu yapılmıştır. Petrole olan bu yüksek bağımlılığın, diğer değerli kaynaklar gibi petrol kaynaklarının iyice azalması ve kıt kaynak olarak görülmesinin, petrol kaynaklarına yönelik artan çıkar 
çatışmalarının sonucu olarak küresel boyutlu savaş ve çatışmalar çıktığının altı çizilmektedir. Bu çatışmalar aktarılmaya çalışılmaktadır.

Kitabın üçüncü bölümünü, 'Basra Körfezi’nde Petrol Savaşı' başl1klı bölüm oluşturmaktadır. Bu bölümde dikkat çeken ilk husus, Basra Körfezi'nin dünya petrol rezervlerinin en büyük kısmını oluşturması olmuştur. Dünya'nın en önemli petrol rezervlerinin olduğu Basra Körfezi aynı zamanda petrol için yaşanan çatışmaların en şiddetli olduğu bölgedir. Enerji arzının güvenliği ve petrol akışının kesintisiz olarak sağlanması, ABD için vazgeçilmez bir politika olduğu belirtilmiştir. Kitabın bu bölümünde, ABD'nin bu gibi gerekçelerle gerek doğrudan gerekse dolaylı yollarla Basra Körfezi'ndeki petrol için yaptığı mücadele ve çıkarlarını korumak için sergilediği tavır geniş bir biçimde ele alınmıştır.

Kitabın dördüncü bölümü 'Hazar Denizi Havzası'ndaki Enerji Savaşı' başlıklı bölümdür. Hazar Denizi Havzası'nın muazzam miktarda doğalgaz ile birlikte dünyanın en büyük ikinci veya üçüncü petrol rezervlerinin barındığı bu bölümde altı çizilen önemli bir husustur. Bu da değerli kaynaklar için yaşanan mücadeleleri beraberinde getirmektedir. Gerek jeopolitik konumu gerekse kaynakları elinde tutmak istemesinden dolayı Rusya, bölgede askeri üstlerle doğrudan müdahil olmayı seçmiştir. Buna karşın ABD’nin ise hem bölgeye olan uzaklığından hem de başka bölgelerdeki yoğun mücadelelerinden dolayı daha çok Hazar Denizi Havzası'ndaki devletlerle politik işbirliğine gittiği ve silahlandırma yarışı içine girdiği belirtilmektedir. Bölümde, buna paralel olarak gerginliklerin artması sonucu çıkan çatışmalara projektör tutulmuştur.

Kitabın, beşinci bölümü olan 'Güney Çin Denizi'nde Petrol Savaşları' başlıklı bölümde, deniz taşıma ticareti için önemli bir kavşak olan Güney Çin Denizi'nin değerli doğalgaz ve petrol rezervlerinin üzerinde bulunduğu düşünüldüğünden kaynak çatışmalarını doğuracağı vurgulanmıştır. Başta Çin ve Japonya olmak üzere bölgedeki diğer devletler arasında hem bu rezervleri elde etmek hem de deniz ticaretinin önemli bir kavşağ1 olan bu suların güvenliğini sağlamak ve kontrolünü elinde bulundurmak için birçok anlaşmazlıklar olduğu ortaya konmuş ve bu anlaşmazlıklardan çıkan çatışmaların resmi çizilmiştir.

Kitabın altıncı bölümünü ise 'Nil Havzası'nda Su Anlaşmazlığı' başlıklı bölüm oluşturmaktadır. Yazar Michael T. Klare, suyun düşünülmeyen bir savaş kaynağı olabileceğine değinmiştir. Ancak tarih boyunca insanların su 
için yaptığı kavgalara şahit olduğumuzu belirtmiştir. Ayrıca, Nil Havası üzerinde de bu durumun yaşandığı, başta Mısır olmak üzere havzadaki diğer devletlerin Nil Havzası üzerinde hâkim olmak ve daha çok yarar sağlamak için geliştirdiği su politikaları yüzünden defalarca karşı karşıya gelindiği, yapılan blöfler ve hızlı silahlanmanın ileride çokça çatışmayı beraberinde getirdiği anlatılmak istenmiştir.

Önemli bir kaynak olan su için başka bir coğrafyada yaşanan mücadeleleri ele alan kitabın yedinci bölümünü oluşturan 'Ürdün, Ftrat-Dicle Nehri ve İndus Havzalarındaki Su Anlaşmazlıkları' başlıklı bölümdür. Artan nüfus oranları sebebiyle yaşamsal değer ve gücün vazgeçilmez kaynağı olan su için Ortadoğu ve Güneydoğu Asya'da insan uygarlığının med cezirini oluşturan bu nehirlerde önemli mücadeleler olduğu görülmektedir. Kitabın bu bölümünde, Ürdün Nehri üzerinde Arap-İsrail çatışmasının, Fırat-Dicle Nehirleri üzerinde Türkiye, Suriye ve Irak arasında yaşanan mücadelelerin ve son olarak da İndus Nehri üzerinde Hindistan ve Pakistan arasindaki anlaşmazlıkların ve çatışmaların üzerinde durulmuştur.

'Dünyanın Zenginlikleri İçin Savaş: Maden ve Kereste İçin İç Savaşlar' başlıklı kitabın sekizinci bölümünde, petrol, doğalgaz ve su gibi kaynaklar kadar olmasa da finansal değeri yüksek diğer kaynaklar için olan çatışmalar gözler önüne serilmektedir. Daha çok Afrika üzerinde olan bu kaynaklar, devleti elinde tutan küçük grupların tekelinde olduğu için gelir dağılımında çok ciddi uçurumlar oluşturmakta olduğu verilen bilgiler arasındadır. Bu grupların, çeşitli uluslararası dev şirketlerin bölgeye girmesine müsaade etmesinin ve elinde bulunan kaynakları ama yasal ama yasal olmayan yollarla satarak gelirlerini iyice artırmasının altı çizilmiştir. Bölümde, yerli halkın bu duruma tepki vermesi ve karşıt grupları silahlandırması sonucu değerli kaynaklar için birçok çatışma ve iç savaş hâsıl olduğu vurgulanmış ve yaşanan çatışmalar anlatılmıştır.

Sonuç kısmı olarak nitelendirilebilecek olan kitabın, 'Çatışmaların Yeni Coğrafyası' başlıklı dokuzuncu bölümünde, kaynaklar için yaşanan bütün bu anlaşmazlık ve çatışmaların süregeleceği öngörülmüştür. Dünya üzerinde kaynakların daha çok Ortadoğu ve Afrika'da yoğunlaştığına dikkat çeken Michael T. Klare, bu coğrafyalarda daha çok çatışma ve savaş çıkabileceğinin altını çizmektedir. Kitabın yazarı Michael T. Klare, ayrıca bütün bu çatışmaların ve anlaşmazlıkların en aza indirilmesi için bazı görüş ve önerilerini de bu bölümde sunmaktadır. 
Sonuç olarak, kitap çağımızın bu önemli sorununu ele almasından dolayı literatüre önemli bir katkı sağladığ ve kaynak teşkil ettiği söylenebilir. İlgi çekici konusu, akıcı anlatımı, konuya dâhil bölgelerin haritalarıyla zenginleştirilmiş eserin, ilgi duyanlarca okunmasını tavsiye ediyorum. 
